\title{
Petrology of the prehistoric lavas and dyke of the Barren Island, Andaman Sea, Indian Ocean
}

\author{
M A Alam ${ }^{* 1}$, D Chandrasekharam ${ }^{1}$, O Vaselli ${ }^{2}$, B Capaccioni $^{3}$, P Manetti $^{4}$ and \\ $\mathrm{P} \mathrm{B} \mathrm{SANTO}^{3}$ \\ ${ }^{1}$ Department of Earth Sciences, Indian Institute of Technology, Bombay, Mumbai 400 076, India \\ ${ }^{2}$ Department of Earth Sciences, University of Florence, Florence 50121, Italy \\ ${ }^{3}$ Institute of Volcanology and Geochemistry, University of Urbino, Urbino 61029, Italy \\ ${ }^{4}$ CNR-Institute of Geosciences and Earth Resources, Pisa 56124, Italy \\ *e-mail: ayaz@iitb.ac.in
}

\begin{abstract}
Although Barren Island (Andaman Sea, Indian Ocean) witnessed several volcanic eruptions during historic times, the eruptions that led to the formation of this volcanic island occurred mainly during prehistoric times. It is still active and currently in the fumarolic stage. Its volcanic evolution appears to be characterized by a constructive phase with the piling up of lava flows and scoria deposits and Strombolian activities, followed by a sudden collapse of the main cone. Deposits of a possible caldera-forming eruption were not recognized earlier. After a period of peri-calderic hydromagmatic activity, whose deposits presently mantle inner and outer caldera walls, a new phase of intracalderic Vulcanian activities took place. A prominent dyke in the SE inner side of the caldera wall was recognized. Petrographically the lava flows and dyke are similar but they differ in their chemical composition (viz., $\mathrm{SiO}_{2}, \mathrm{MgO}, \mathrm{Ni}, \mathrm{Cr}$ ) significantly. Similarity in major, minor and trace element composition (viz., K/La, K/Nb, K/Rb, K/Ti ratios) of these rocks together with Chondrite normalized trace element (Rb, Ba, Sr, P, Zr, Ti and $\mathrm{Nb}$ ) and REE ( $\mathrm{La}, \mathrm{Ce}, \mathrm{Nd}$ and $\mathrm{Y}$ ) patterns of the Barren Island prehistoric lava flows and dyke and low-K lavas of Sunda Arc indicates that Barren Island must have evolved from a source similar to that of Sunda Arc lavas during the Quaternary Period.
\end{abstract}

\section{Introduction}

Barren Island (Andaman Sea, Indian Ocean) has witnessed several volcanic eruptions during historic times: 1994-95, 1991, 1852?, 1803-04, 1795, 1789, 1787 (Raina 1987; Haldar 1989; Haldar et al 1992ab, 1995; Ravi Shanker et al 2001; Haldar and Luhr 2003). The present morphology of the island is firstly the result of a huge collapse event affecting the central part of a pre-existing volcanic cone. This event probably occurred during the prehistoric time, viz., late Pleistocene? (Ravi Shanker et al 2001). This prehistoric eruption is represented by the caldera wall, which forms a ridge all around the island. All the later eruptions were confined to the central part of this caldera depression. Bandyopadhyay et al (1973) reported that the lava pile of the caldera wall was traversed by dykes, but no details about their location, disposition, petrography and chemistry were provided.

A dyke was found by the authors during their field investigations in February 2003 (Smithsonian Institution 2003). The petrography and chemistry of this dyke and the prehistoric lavas, which it has intruded, are the subjects of this paper.

\section{Location and geology}

Barren Island $\left(12^{\circ} 16^{\prime} 40^{\prime \prime} \mathrm{N}, 93^{\circ} 31^{\prime} 00^{\prime \prime} \mathrm{E}\right)$, a small volcanic island in the Indian Ocean and a part

Keywords. Barren Island; lava flows; dyke; petrology; Sunda Arc. 
of the Andaman and Nicobar chain of islands, is the only active volcano in the Indian subcontinent region. It is located $135 \mathrm{~km}$ northeast of Port Blair in east Andaman Sea. It belongs to the Neogene Inner Volcanic Arc (Haldar et al 1992a) extending from the extinct volcanoes like Mt. Popa and Mt. Wuntho of Myanmar in the north to the active volcanoes of Sumatra and Java in the south (figure 1). The island itself is a result of eruptions during the late Pleistocene time (Ravi Shanker et al 2001). The elevation of the prehistoric cone was estimated to be about $1100 \mathrm{~m}$, with its base having a diameter of about $12 \mathrm{~km}$, taking into consideration the outer slope of the caldera wall $\left(\sim 32^{\circ}\right)$ and the present subaerial diameter $(3.5 \mathrm{~km})$ of the island (Bandyopadhyay et al 1973; Raina 1987).

The northern and north-western parts of the caldera have been mantled by a $\sim 50 \mathrm{~m}$ thick monotonous sequence of breccias and tuff representing syn/post-caldera phreatic and hydromagmatic activities. While the eruptive activities during and immediately following the caldera formation were mostly hydromagmatic and from the rim of the caldera itself, the historic and recent eruptions occurred from its centre, producing a $250 \mathrm{~m}$ high polygenetic tuff cone. The caldera depression could have formed either by a giant, non-eruptive lateral landslide of the original cone or by vertical collapse of a surficial magma chamber as a result of a paroxysmal eruption of which we have no depositional evidence.

On the caldera wall the pre-caldera activity is represented by six lava flows separated by scoria beds and minor tuff and cinder deposits. The lava flows vary in thickness from 2 to $3 \mathrm{~m}$, while the other volcanic materials vary in thickness from 1 to $4 \mathrm{~m}$. These flows occur towards the northern part of the main caldera, which is devoid of vegetation. Towards the south-eastern part of the inner caldera a $5 \mathrm{~m}$ wide, NNE-SSW trending dyke is observed. It is exposed in the flows of the caldera wall at an elevation of about $140 \mathrm{~m}$ towards the southern flank of a talus cone and is located at $\mathrm{N} 12^{\circ} 16^{\prime} 41.0^{\prime \prime}$, E93 ${ }^{\circ} 51^{\prime} 27.3^{\prime \prime}$. The outer portion of the dyke is weathered and lighter in colour, whereas the inner portion is fresh and darker in colour. The dyke is fine to medium grained and contains buff coloured olivine, green pyroxene and a large number of plagioclase phenocrysts. The dyke is thus basaltic.

\section{Petrography and mineral chemistry}

The prehistoric lava flows along the caldera wall are dark grey to greyish white in colour and at places deep brown. They are largely phyric with megacrysts and microphenocrysts of

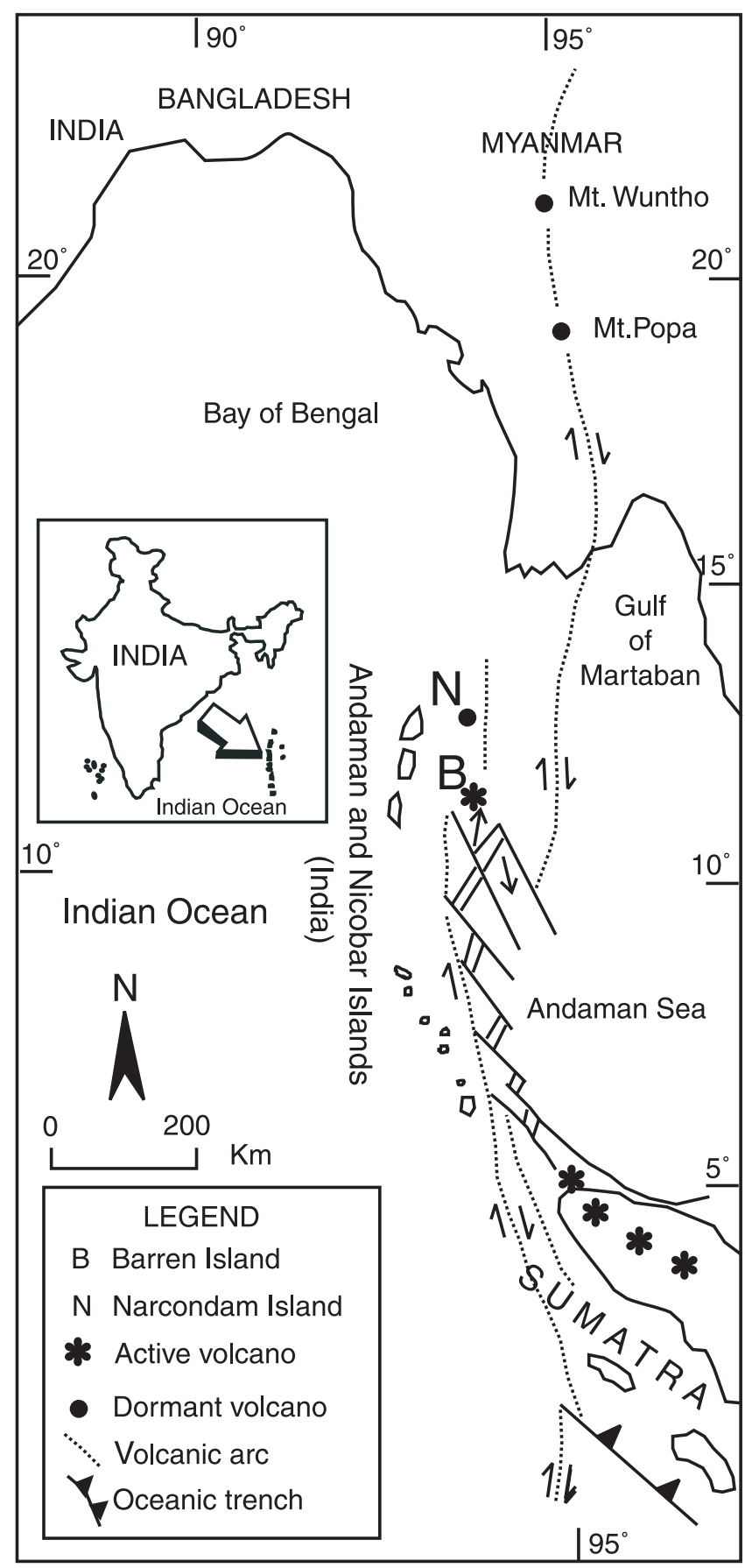

Figure 1. Location of Barren Island on the Neogene Inner Volcanic Arc (modified after Rodolfo 1969).

plagioclase, olivine (greenish but dark red or brown when altered) and green pyroxene in fine grained grey to dark grey groundmass. Microscopically they show megacrysts and microphenocrysts of highly zoned plagioclase $\left(\mathrm{An}_{69-93 \%}\right.$, $\left.\mathrm{Ab}_{7-30 \%}, \mathrm{Or}_{0-1 \%}\right)$ olivine $\left(\mathrm{Fo}_{66}-83 \%\right)$ orthopyroxene $\left(\mathrm{En}_{70-99 \%}, \mathrm{Fs}_{0-26 \%}, \mathrm{Wo}_{1-4 \%}\right)$ clinopyroxene $\left(\mathrm{En}_{44-46 \%}, \mathrm{Fs}_{9-19 \%}, \mathrm{Wo}_{37-47 \%}\right)$. Mineral compositions were determined using Electron Probe Microanalysis (EPMA) at University of Florence, Italy. 
Table 1. Major and trace element data for Barren Island rocks.

\begin{tabular}{|c|c|c|c|c|c|c|c|}
\hline Sample & BAR3 & BAR4 & BAR5 & BAR13 & BAR17 & BAR18 & BAR19 \\
\hline \multicolumn{8}{|l|}{$\mathrm{wt} \%$} \\
\hline$\overline{\mathrm{SiO}_{2}}$ & 48.82 & 49.63 & 53.48 & 50.46 & 51.12 & 50.81 & 52.19 \\
\hline $\mathrm{Al}_{2} \mathrm{O}_{3}$ & 16.68 & 16.68 & 17.67 & 18.58 & 21.29 & 18.25 & 20.58 \\
\hline $\mathrm{FeO}_{\mathrm{t}}$ & 7.88 & 7.97 & 7.07 & 7.63 & 7.02 & 7.39 & 6.86 \\
\hline $\mathrm{MgO}$ & 10.88 & 11.04 & 6.65 & 7.73 & 3.89 & 7.82 & 4.65 \\
\hline $\mathrm{CaO}$ & 10.71 & 10.87 & 9.82 & 11.31 & 11.28 & 10.63 & 10.32 \\
\hline $\mathrm{Na}_{2} \mathrm{O}$ & 2.33 & 2.41 & 3.21 & 2.44 & 2.95 & 2.71 & 3.28 \\
\hline $\mathrm{K}_{2} \mathrm{O}$ & 0.27 & 0.31 & 0.46 & 0.26 & 0.39 & 0.31 & 0.51 \\
\hline $\mathrm{TiO}_{2}$ & 0.74 & 0.75 & 0.68 & 0.70 & 0.81 & 0.65 & 0.83 \\
\hline $\mathrm{MnO}$ & 0.15 & 0.15 & 0.15 & 0.15 & 0.15 & 0.16 & 0.14 \\
\hline $\mathrm{P}_{2} \mathrm{O}_{5}$ & 0.08 & 0.08 & 0.11 & 0.07 & 0.10 & 0.08 & 0.14 \\
\hline LOI & 0.01 & 0.48 & 0.01 & 0.45 & 0.40 & 0.42 & 0.32 \\
\hline Total & 98.55 & 100.37 & 99.31 & 99.78 & 99.4 & 99.23 & 99.82 \\
\hline \multicolumn{8}{|l|}{ ppm } \\
\hline$\overline{\mathrm{La}}$ & 5.0 & 4.2 & 6.1 & 4.8 & 5.1 & 4.4 & 7.9 \\
\hline $\mathrm{Ce}$ & 11.5 & 11.6 & 13.4 & 7.4 & 12.7 & 11.9 & 18.2 \\
\hline $\mathrm{Nd}$ & 7.1 & 9.8 & 9.1 & 6.3 & 8.7 & 7.7 & 10 \\
\hline $\mathrm{Nb}$ & 0.7 & 0.6 & 0.8 & 0.4 & 0.6 & 0.5 & 2.1 \\
\hline $\mathrm{Zr}$ & 51 & 50 & 72 & 49 & 62 & 55 & 77 \\
\hline $\mathrm{Y}$ & 20 & 20 & 24 & 21 & 23 & 20 & 24 \\
\hline $\mathrm{Sr}$ & 203 & 204 & 199 & 177 & 216 & 187 & 250 \\
\hline $\mathrm{Rb}$ & 5.6 & 5.3 & 8.8 & 5.9 & 10 & 5.4 & 11.2 \\
\hline $\mathrm{Zn}$ & 69 & 65 & 71 & 68 & 70 & 60 & 63 \\
\hline $\mathrm{Cu}$ & 70 & 55 & 59 & 73 & 82 & 37 & 58 \\
\hline $\mathrm{Ni}$ & 218 & 216 & 76 & 100 & 22 & 95 & 42 \\
\hline $\mathrm{Cr}$ & 496 & 508 & 216 & 241 & 36 & 249 & 81 \\
\hline V & 257 & 263 & 216 & 253 & 286 & 201 & 220 \\
\hline $\mathrm{Ba}$ & 71 & 66 & 98 & 61 & 70 & 77 & 107 \\
\hline $\mathrm{Sc}$ & 34 & 36 & 33 & 36 & 29 & 29 & 28 \\
\hline
\end{tabular}

$\mathrm{FeO}_{\mathrm{t}}$ : Total iron as FeO.

LOI: Loss in weight on ignition.

Olivine grains are traversed by iddingsite, while plagioclase megacrysts show shattering effect at places. These megacrysts and microphenocrysts are embedded in a groundmass of dark coloured glass with microlites of plagioclase and globules of clinopyroxene and Fe-Ti oxides. Groundmass texture of the lava flows differs from flow to flow and varies from holocrystalline to aphanitic and shows intersertal to fluidal texture. Plagioclase megacrysts are characterised by multiple twinning and contain abundant small inclusions of glass and groundmass material zonally arranged or clustered in the central part of the crystal with the peripheral part of the grain corroded and surrounded by glass. Olivine megacrysts are mostly corroded and broken. Melt inclusions grains are often seen in the olivine grains.

The prehistoric dyke has a similar mineralogical composition to the flows of the caldera wall, but differs in its grain size, the flows having a smaller grain size. Mineralogical composition of the two is similar. The dyke also has a greater amount of olivine.

\section{Whole rock chemistry}

Whole-rock analyses were carried out by using Xray fluorescence spectrometry (Philips PW 1480 spectrometer equipped with an Rh-anode X-ray 


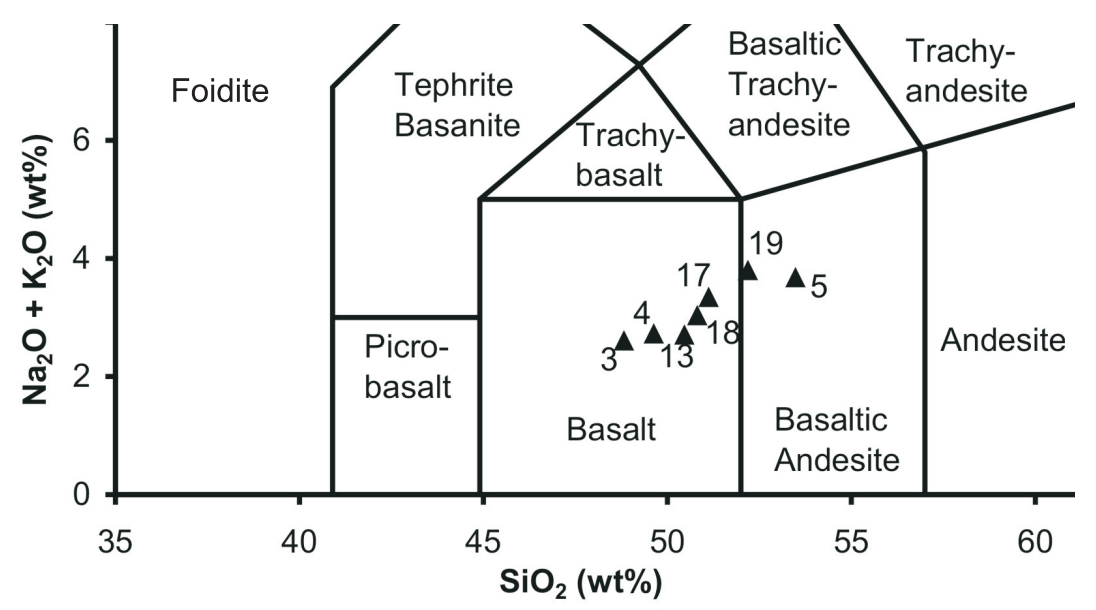

Figure 2. Total Alkali vs. Silica (TAS) diagram (Le Bas et al 1986).

tube) at the Department of Earth Sciences, University of Edinburgh, UK. The instrument was calibrated using international reference samples (Govindaraju 1994). Major elements were determined on fused glass discs (Norrish and Hutton 1969) with corrections applied for inter-element mass absorption effects. Trace elements were determined on pressed powder discs and count-rates were corrected for line-overlap and mass absorption effects. Description of the technique, analytical conditions and precision estimates are given in Fitton et al (1998).

The prehistoric lava flows (samples BAR5, BAR13, BAR17, BAR18 and BAR19) and dyke (samples BAR3 and BAR4) have similar major element composition (table 1), but differ in their $\mathrm{MgO}$ content significantly. $\mathrm{MgO}$ content of the dyke is $\sim 11 \mathrm{wt} \%$, whereas it is < wt $7 \%$ in the flow. The high content of $\mathrm{MgO}$ in the dyke is not duplicated in any of the flows. They also differ in their $\mathrm{SiO}_{2}$, total iron as $\mathrm{FeO}, \mathrm{CaO}$ contents as well, but to a lesser extent. Weight loss on ignition (LOI) values for the samples provides a rough idea of the subaerial alteration suffered by the rocks. Very low LOI values for both flows and dyke rocks $(<0.5 \mathrm{wt} \%)$ show that these rocks are not much altered and hence the possibility of redistribution of the mobile elements is very small.

The composition of the dyke (samples BAR3 and BAR4) is basalt and the lava flows are basalt (samples BAR13, BAR17 and BAR18) and basaltic andesite (samples BAR5 and BAR19) as shown in the Total Alkali vs. Silica (TAS) diagram (Le Bas et al 1986) (figure 2). However from the AFM diagram (figure 3) for both the dyke (samples BAR3 and BAR4) and flows (samples BAR5, BAR13, BAR17, BAR18, and BAR19) tholeiitic trend is evident. Trace element compositions (table 1) of the flows (BAR5, BAR13, BAR17, BAR18 and BAR19) and the dyke (BAR3 and BAR4) are sim-

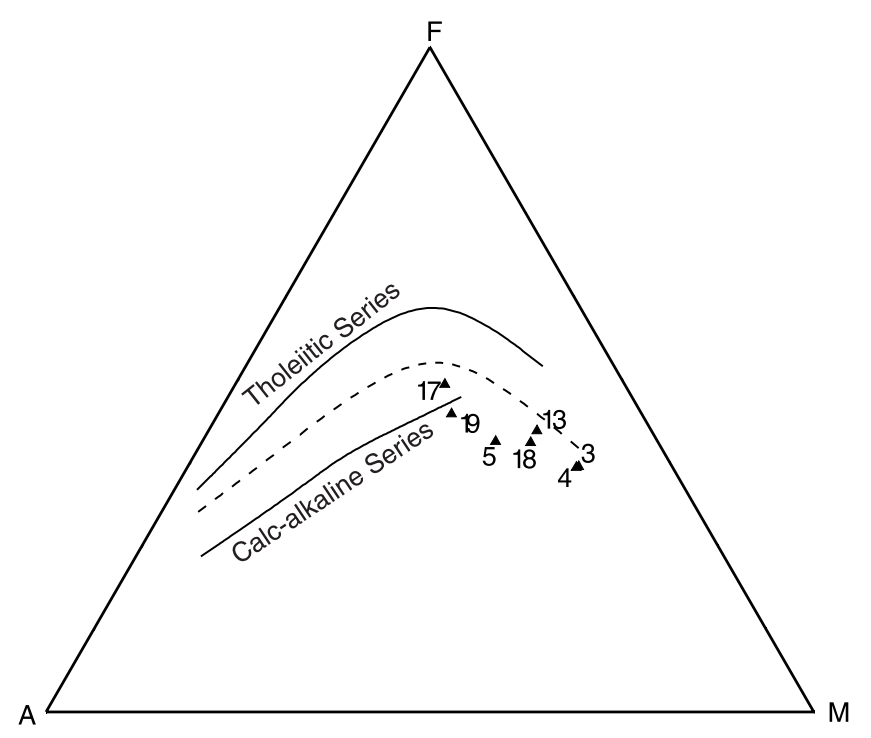

Figure 3. Barren Island samples on the AFM diagram (after Irvine and Baragar 1971)

ilar (viz., concentration of La, Ce, Nd, Nb, Y, Sr, $\mathrm{Rb}, \mathrm{Ba}, \mathrm{Zn}, \mathrm{Cu}$ and $\mathrm{Sc}$ ). In the dyke, concentrations of $\mathrm{Ni}$ and $\mathrm{Cr}$ are more than twice those in the flows.

\section{Discussion and conclusions}

The high $\mathrm{MgO}$ content of the dyke is not duplicated in any of the flows of the caldera wall. High $\mathrm{MgO}$ together with $\mathrm{Ni}$ and $\mathrm{Cr}$ contents of the dyke may suggest its deeper mantle origin a different degree of evolution at a higher crustal level or an olivine cumulate.

The most significant feature of these rocks, both dyke and flows, is their similarity in major, minor and trace element chemistry and $\mathrm{K} / \mathrm{La}, \mathrm{K} / \mathrm{Nb}$, $\mathrm{K} / \mathrm{Rb}, \mathrm{K} / \mathrm{Ti}$ ratios (figure 4 ) to the Quaternary 
(a)

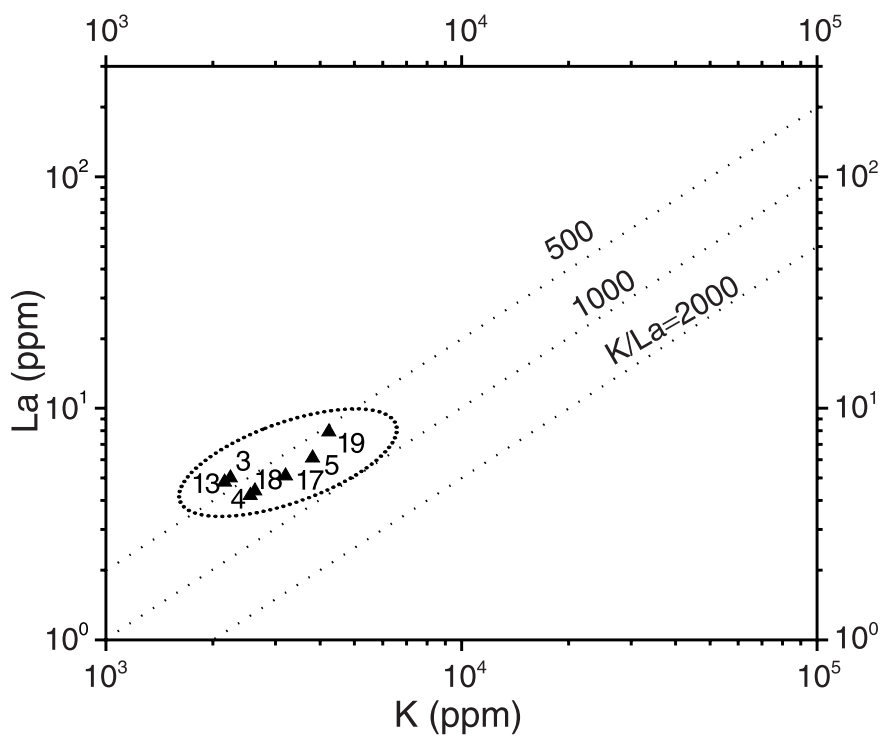

(b)

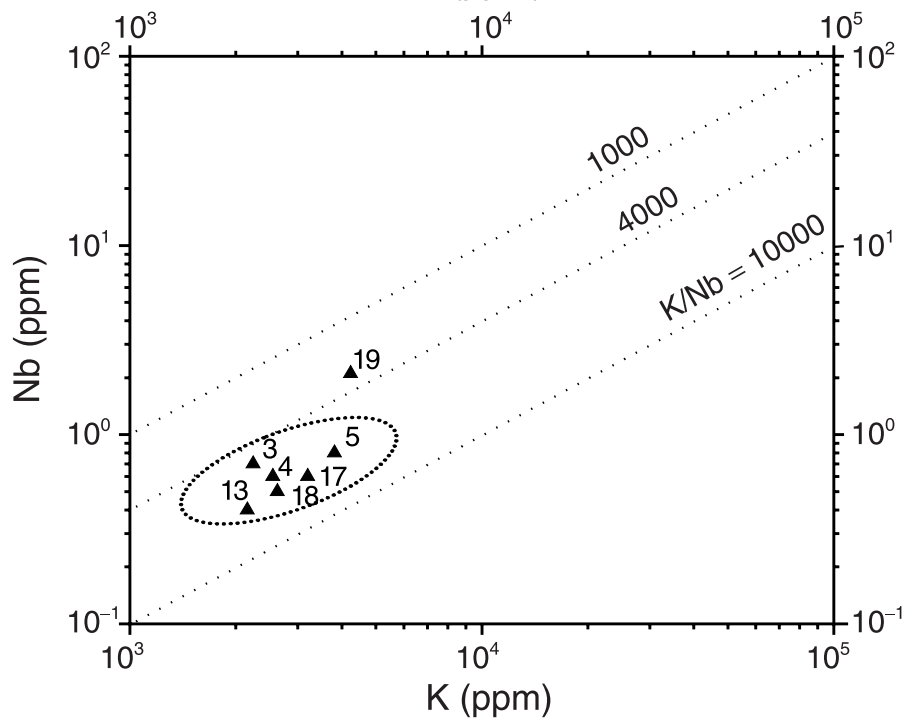

(c)

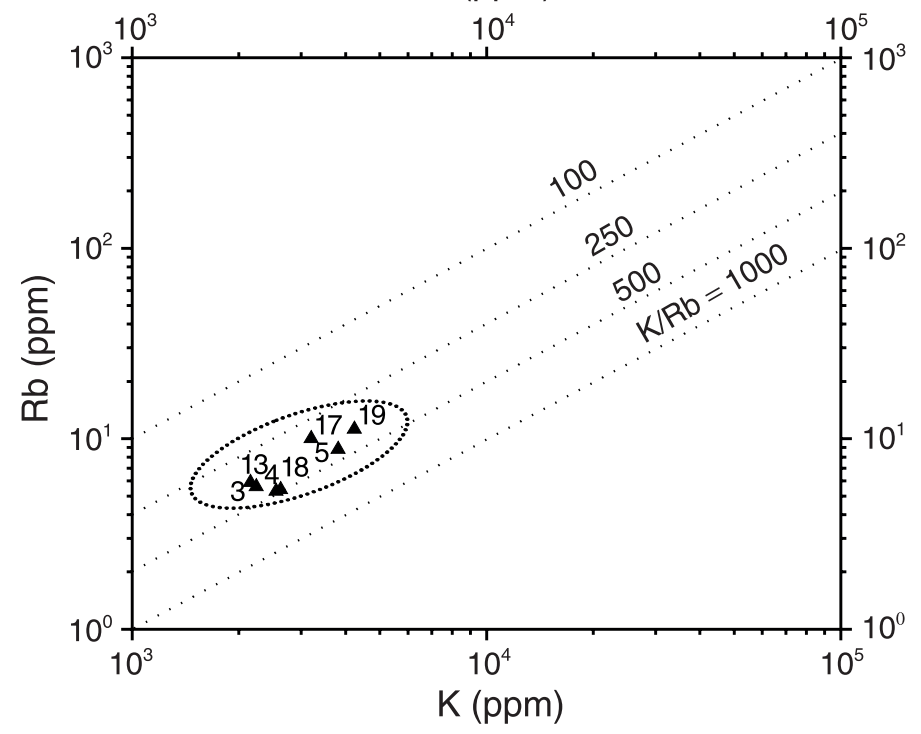

Figure 4. (Continued) 


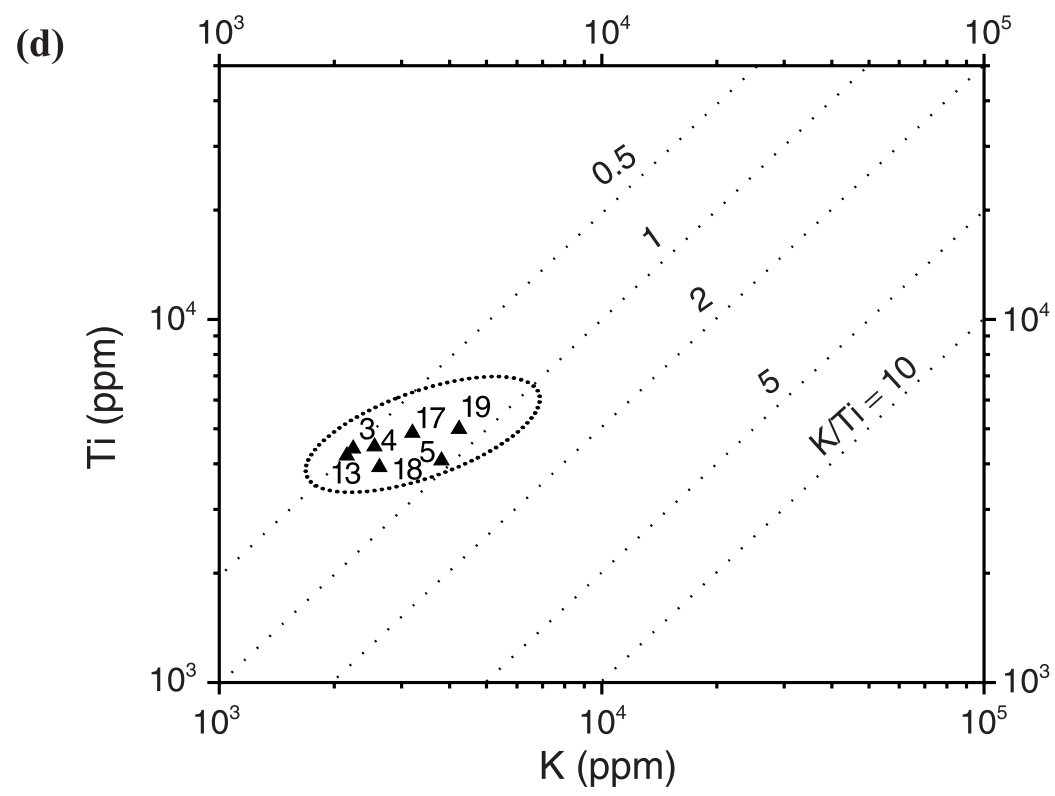

Figure 4. Discriminatory diagrams (K/La, K/Nb, K/Rb, K/Ti) for the rocks of Barren Island (dotted fields are those of low-K Sunda Arc lavas, Wheller et al 1987).

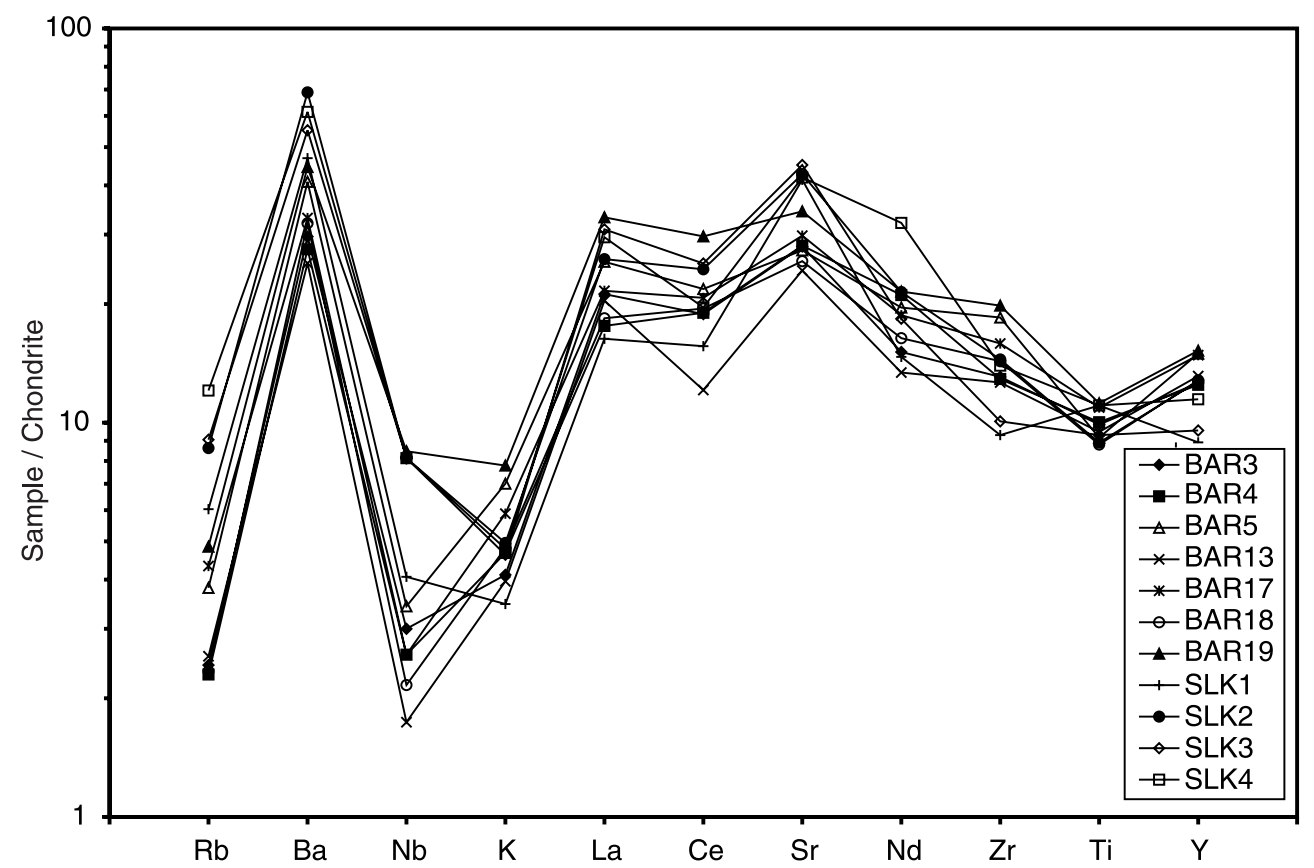

Figure 5. Spider diagram of the trace elements normalised to C1-Chondrite (Sun and McDonough 1989) for the prehistoric lava flows (BAR5, BAR13, BAR17, BAR18 and BAR19) and dyke (BAR3 and BAR4) of Barren Island and low K lava flows of Sunda Arc (SLK1, SLK2, SLK3 and SLK4; Wheller et al 1987).

low-K volcanic rocks of Sunda Arc, Indonesia. C1Chondrite (Sun and McDonough 1989) normalised trace element and REE pattern (figure 5) of the Barren Island flows and Sunda Arc low-K lavas (Wheller et al 1987) are closely similar. Such a striking similarity between prehistoric flows and dyke of Barren Island and low K lavas of Sunda Arc indicates that Barren Island lavas may have evolved from a source similar to that of the Sunda Arc lavas during the Quaternary period and is still active. Barren Island volcano is currently in the fumarolic stage (Smithsonian Institution 2003). 


\section{Acknowledgement}

The authors thank the Indian Coast Guard for extending support during the fieldwork. M A Alam thanks the Head, Department of Earth Sciences and the Director, Indian Institute of Technology Bombay, India for providing facilities to carry out this work. Authors thank Dr Robert Hall, Dr Angelo Peccerillo, Dr Francoise Chalot-Prat and Dr James F Luhr for critical reviews of the manuscript.

\section{References}

Bandyopadhyay S, Subramanyam M R and Sharma P N 1973 The geology and mineral resources of Andaman and Nicobar Islands; Rec. Geol. Surv. India 105(2) 25-68

Fitton J G, Saunders A D, Larsen L M, Hardason B S, Norry M J 1998 Volcanic rocks from the Southeast Greenland margin at $63^{\circ} \mathrm{N}$ : composition, petrogenesis and mantle sources. In: Proceedings of the ODP: Scientific Results (eds) A D Saunders, H C Larsen, S H Wise, College Station, TX (Ocean Drilling Program) 152 331-350

Govindaraju K 1994 Compilation of working values and sample description for 383 geostandards; Geostandards Newsletter 18 1-158

Haldar D 1989 Petrology and chemistry of recent volcanics of Barren and Narcondam islands - the only two recent volcanoes in India; Rec. Geol. Surv. India 122(3) 48-49

Haldar D and Luhr J F 2003 The Barren Island volcanism during 1991 and 1994-95: eruptive style and lava petrology; Mem. Geol. Soc. India 52 313-338

Haldar D, Chakraborty S C and Chakraborty P P 1995 The 1995-eruption of the Barren Island volcano in the Andaman Sea; Rec. Geol. Surv. India 129(3) 59-61
Haldar D, Lasker T, Bandyopadhyay P C, Sarkar N K and Biswas J K 1992a The volcanic eruption of the Barren Island volcano, Andaman Sea; J. Geol. Soc. India 39(5) 411-419

Haldar D, Lasker T, Bandyopadhyay P C, Sarkar N K and Biswas J K 1992b A note on the recent eruption of the Barren Island Volcano; Ind. Minerals 46(1) 77-88

Irvine T N and Baragar W R A 1971 A guide to the chemical classification of the common volcanic rocks; Can. J. Earth. Sci. 8 523-548

Le Bas M J, Le Maitre R W, Streckeisen A and Zanettin B 1986 A chemical classification of volcanic rocks based on the total alkali-silica diagram; J. Petrol. 27 745-750

Norrish K and Hutton J T 1969 An accurate X-ray spectrographic method for the analysis of a wide range of geological samples; Geochim. Cosmochim. Acta 33 431453

Raina V K 1987 A note on sulphur occurrence in the volcanoes of the Bay of Bengal, Ind. Minerals, 41(3) 79-86

Ravi Shanker, Haldar D, Absar A and Chakraborty S C 2001 Pictorial monograph of Barren Island volcano: the lone active volcano in the Indian Subcontinent; Geol. Surv. India Sp. Pub. $6788 \mathrm{p}$

Rodolfo K S 1969 Bathymetry and marine geology of the Andaman Basin and tectonic implications for Southeast Asia; Geol. Soc. Am. Bull. 80 1203-1230

Smithsonian Institution 2003 Barren Island: Fumarolic activity noted during fieldwork in February 2003; Bull. Glob. Volc. Net. 23 12-14

Sun S S and McDonough W F 1989 Chemical and isotopic systematics of oceanic basalts: implications for mantle composition and processes; In: Magmatism in the Ocean Basins (eds) A D Saunders and M J Norry Geol. Soc. London Sp. Pub. 42 313-345

Wheller G E, Varne R, Foden J D and Abbott M J 1987 Geochemistry of Quaternary volcanism in the Sunda-Banda Arc, Indonesia and three component genesis of island arc basaltic magmas; J. Volcanol. Geotherm. Res. 32 137160 